\title{
Article \\ Systemic Insights on the Integration of UN Sustainable Development Goals within the Norwegian Salmon Value Chain
}

\author{
Mohd Abualtaher*(D), Turid Rustad (D) and Eirin Skjøndal Bar \\ Department of Biotechnology and Food Science, NTNU—Norwegian University of Science and Technology, \\ 7491 Trondheim, Norway; turid.rustad@ntnu.no (T.R.); eirin.bar@ntnu.no (E.S.B.) \\ * Correspondence: mohd.h.m.abualtaher@ntnu.no; Tel.: +47-9682-2638
}

check for updates

Citation: Abualtaher, M.; Rustad, T.; Bar, E.S. Systemic Insights on the Integration of UN Sustainable Development Goals within the Norwegian Salmon Value Chain. Appl. Sci. 2021, 11, 12042. https:// doi.org/10.3390/app112412042

Academic Editor: Tiago Verdelhos

Received: 8 September 2021

Accepted: 13 December 2021

Published: 17 December 2021

Publisher's Note: MDPI stays neutral with regard to jurisdictional claims in published maps and institutional affiliations.

Copyright: (c) 2021 by the authors. Licensee MDPI, Basel, Switzerland. This article is an open access article distributed under the terms and conditions of the Creative Commons Attribution (CC BY) license (https:// creativecommons.org/licenses/by/ $4.0 /)$.

\begin{abstract}
This study proposes a conceptual framework that aims to gain insight into the integration of the sustainable development goals (SDG) within the Norwegian salmon value chain (NSVC). The proposed framework was developed by applying the systems engineering six-step method and validated through empirical findings from the NSVC. The framework's application highlighted and analyzed the presence of the SDGs in corporate sustainability reports, academic curriculum, research, and governmental policies. This study uncovered the complexity-reduction elements within the system that drive SDG integration and assure their progress. The SDGs provide a global context for sustainability endeavors in the NSVC. A globally expanded value chain has an organic relationship with global sustainability terms and schemes. The existing practice of corporate sustainability annual reporting was found to be a significant channel for SDG communication. The novelty of this study was that it proposed a mind-map to understand SDG integration within an industrial value chain abstracted into three concepts: commitment, communication, and performance measurability.
\end{abstract}

Keywords: systems; sustainability; aquaculture; salmon

\section{Introduction}

Sustainable development can be seen as an anthropocentric view of the inter-relationships between environmental and socio-economic issues [1]. On its seventieth anniversary in September 2015, the United Nations (UN) general assembly adopted the resolution, "Transforming our world: the 2030 Agenda for Sustainable Development". With its 17 sustainable development goals (SDG) and 169 targets, Agenda 2030 presented a plan to achieve a vision of a peaceful world free from hunger, poverty, and environmental deterioration, a world of prosperity and the efficient use of natural resources for all [2]. Agenda 2030 is a call for partnership, solidarity, and mobilization of all efforts at all levels [3]. In July 2017, the UN general assembly added a total of 231 measurable indicators under the SDG framework, introducing a layer of complexity of SDG interactions that needs to be unraveled to optimize the benefits of their implementation [4]. There is a consensus among governments, experts, and researchers that a localization process is necessary to realize the SDGs at the level of locally and regionally driven operations [5]. The 2030 Agenda emphasized the need for inclusive participation and stakeholder engagement for the successful implementation of the goals. Nonetheless, the SDG framework is perceived as a top-down approach and criticized for an insufficient focus on systems stakeholders' perspectives and the potential role of businesses [6]. SDG achievement depends on the integration of SDGs into local business practices, created policies, internal education, active management, and engagement in partnerships [7]. Moreover, SDG integration in corporate culture is associated with a paradigm shift toward shared values of a sustainable future, as demonstrated by the SDGs [6]. Businesses can derive clear objectives from the SDG global priorities, aligned with governmental policies, societal interests, and appeal for private sector investors [8]. The formation of multi-stakeholder partnerships for SDG implementation is an opportunity that benefits both governmental and non-governmental actors [9]. 
Education is placed at the heart of Agenda 2030 and SDG implementation and educating business leaders and society about the goals of the agenda is a necessary precursor for local integration [10]. Universities have the capacity to lead the cross-sectoral integration of the SDG, not only by educating the professional work force in the targeted sectors, but also by initiating cross sectoral communication among the different stakeholders and providing research-based contributions [11]. In local contexts, the implementation and monitoring must be operationalized within the national, sub-national, and local structures, processes, and practices [12]. While many firms and corporations around the world are struggling to develop a definition of sustainability and its associated requirements to both guide and scope their efforts, the SDGs provide a guiding vision to achieve sustainability as a result of collective international endeavors [13]. The SDGs are creating a platform for a systemic sustainability transition and providing relatively well-defined terms for relevant communications. Successful implementation of the SDG targets is seen as a promising way forward to achieve global sustainability [14]. SDG achievement requires a shift in mindset from transition to transformation in research, innovation, technology, and policy [15]. The integration of the SDGs within a system is a powerful catalyst for the system's development and increased efficiency $[16,17]$. There is a proven correlation between SDG integration and communication maturity [7]. SDG fulfillment depends on their reflection in the knowledge systems used to develop mission statements, action plans, corporate reports, and other business tools [18]. One of the main challenges facing SDG implementation is the limited availability of the relevant performance data due to a delay in quantifying and monitoring SDG indicators [19].

Systems engineering (SE) is defined as a methodical, multi-disciplinary approach for the design, realization, technical management, operation, and retirement of a system [20]. SE is a discipline of knowledge that can help businesses to provide significant social, environmental, and economical global benefits by turning the policy intentions into requirements for consistent delivery through enterprises and practical systems [21]. SE has been an active supporting discipline for the implementation of the SDGs through providing effective approaches and toolsets to reframe the SDGs [22]. The International Council on Systems Engineering (INCOSE) introduced its Vision 2025 for Systems Engineering, in which they promote the role of systems engineers in approaching the world's complicated challenges of sustainability and the growing stress on natural resources. Vision 2025 resulted from multidisciplinary work by leaders from industry, academia, and government. Vision 2025 reaffirmed the SE concepts of a multidisciplinary approach and stakeholders expectations as a driver for a system's transition, a product's full life-cycle management, and data management [23].

Norwegian salmon value chain (NSVC). For several years Norway has been the world's second-largest seafood exporter. Seafood is the second-largest export product category in the Norwegian economy [24]. In Norway, the salmon industry is widely perceived as an economic success story [25,26]. Seafood value chains are not limited to the entities or activities of wild fisheries, aquaculture, and seafood processing, but also encompass and influence other industries [27]. The Norwegian salmon value chain includes aquaculture production, the salmon-feed industry, and postharvest processing [28]. Farmed Atlantic salmon (Salmo salar) in Norway is a significant contributor to the Norwegian economy and in 2019 it recorded a total revenue of about seven billion USD [29]. The world's largest salmon producers are Norwegian [30]. NSVC earns most of its revenue by exporting more than $90 \%$ of its production. The salmon industry in Norway employs thousands of people, and the numbers continue to increase [31]. NSVC represents all the activities necessary to transform primary input raw material into the output food product. The central activity of growing the salmon takes place in sea-cages at farming sites in the Norwegian marine environment. The salmon-feed industry is an important part of the NSVC; the feed is made using imported ingredients mainly from South America [32]. The salmon product is exported to the global market, including Japan, China, Europe, the Middle East, North America, and more. Because the NSVC imports raw feed ingredients from several countries 
and most of the final product is exported to countries all over the world, the NSVC can be described as a global value chain. The major sustainability challenges facing the NSVC, as frequently reported in the literature, are the following: sea lice parasites [33], fish escapees from the sea-cages in the farming sites to the surrounding marine environment [34,35], and the environmental footprint of the imported feed ingredients [36-40]. The efficiency in nutrient utilization management, starting from feed production all the way to postharvest byproducts, receives steady focus in NSVC sustainable development research [32,41-43].

This study's main purpose is to develop a systems engineering-based framework for gaining insight into the SDG integration process within the Norwegian salmon value chain. The proposed framework will be applied and its outcomes will be discussed.

\section{Methods}

\subsection{Framework Development}

The SE approach for developing a framework for the purpose of gaining insight on SDG integration within the NSVC in this study was guided by the rationale sequence of the six-step SE method [44-46], summarized in Figure 1. The six-step method starts by $1-$ identifying needs, based upon a stakeholder analysis; 2 -defining requirements, based on needs; 3 -specifying performance, system activities, and progress indicators; 4-analyzing the gathered information to conceptualize a model for the drivers of the performance; 5-designing, solving, and improving; 6-verifying, testing, and implementing.

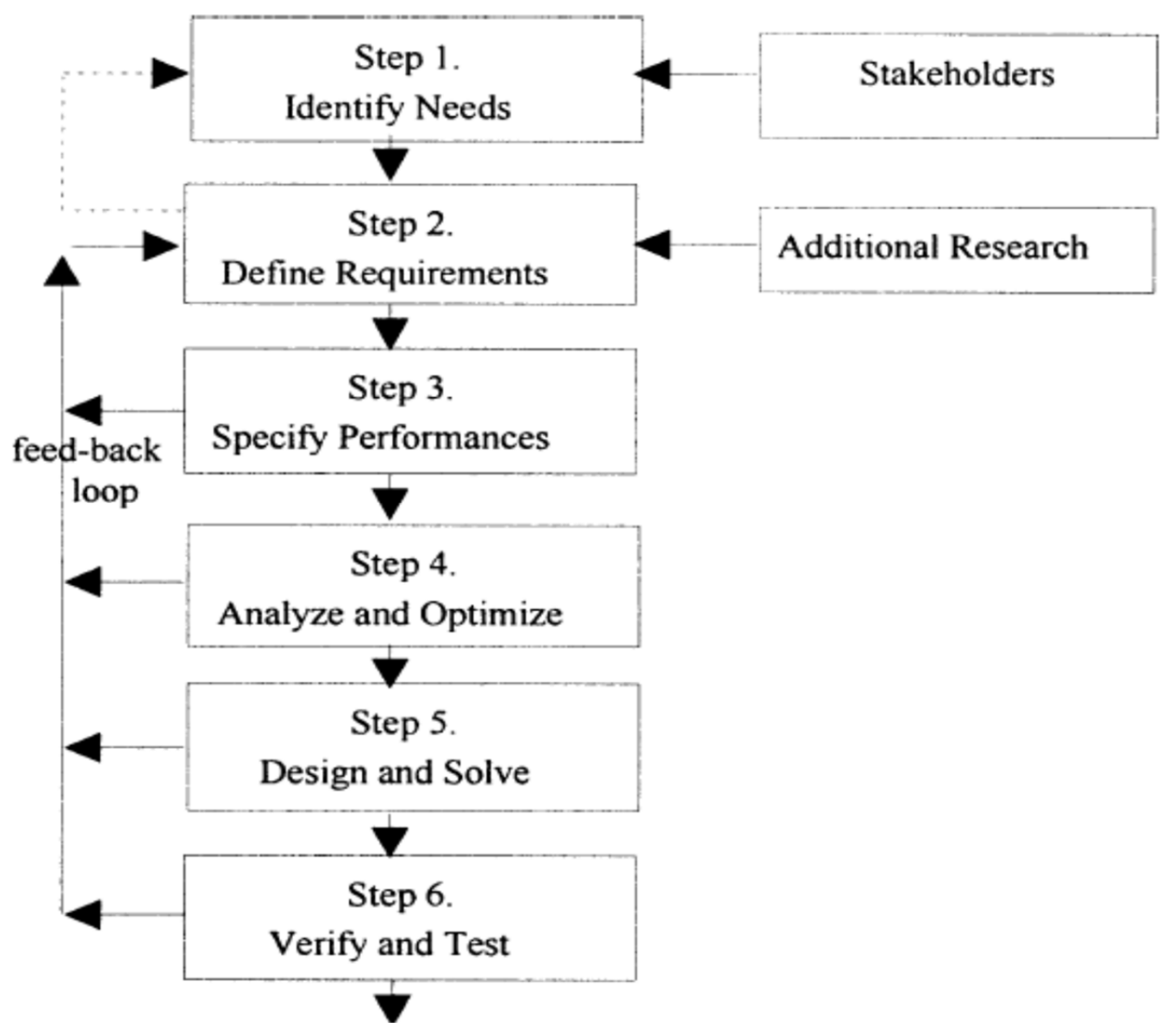

Figure 1. The systems engineering six steps method [47]. 


\section{Step 1: Identify the needs.}

What are the endeavors and resources being deployed by the NSVC stakeholders to allow SDG integration into the system's culture and practices? We need to know in which form the SDGs will materialize in the industrial operational structure.

In this study, SDG integration in an industrial value chain is understood according to how far the concepts and values of the SDGs are conveyed to the value chains as functioning mechanisms for change. The SDG framework was preceded by the Agenda 2030 declaration and followed by the global indicators framework. In logical order, it started with obtaining world governments' commitment, followed by releasing the SDG framework that stressed the importance of creating partnerships through efficient and transparent communication, specified in SDG 17. Later, the global indicator framework was announced, as a support for the implementation through the concept of performance measurement. Derived from the given logical order, the framework is based on commitment, communication, and performance measurability as core concepts to include in the framework. The defined key concepts in the UN SDG framework (summarized in Table 1) should be interweaved with SE principles. UN Agenda 2030 started with the announced commitment from governments on behalf of the people they represent and serve. Achieving the SDG requires strategic commitment from all stakeholders [48]. Commitment to the SDG is a value that flows top-down through the system. The SDG framework clearly states that multistakeholder partnerships and voluntary commitments (SDG number 17) are musts for SDG achievement. The global indicator framework for measuring the performance of SDG implementation was developed for performance measurement in achieving the SDG goals [14,49]. Communication plays a central role in almost every aspect of effective partnership to achieve the SDGs. Partnerships between stakeholders from all interests, scales, sectors, and organizational cultures require forming a shared understanding to think creatively and ambitiously about possible solutions. Within an industrial value chain, sharing information between functions provides adequate visibility and enables the making of good decisions [50]. Reaching an advanced level of goal-oriented functioning requires effective, transparent, and sufficient communication. The flow of SDG-relevant information through the system will be in multiple forms of communication, which will be unique to each partnership [51]. Business organizations reporting on the SDGs can support the planning, implementation, measurement, and communication of their efforts to achieve the SDGs [52]. The practice of corporate sustainability reporting can raise the level of transparency in communication about companies' activities, enhance stakeholders' confidence, and serve the SDG implementation and performance measurement [51,53]. The importance of communication about SDGs among all the stakeholders was frequently highlighted in the relevant UN literature and official statements. UN Secretary-General Ban Ki-Moon in 2015 said: "Business is a vital partner in achieving the SDG, companies can contribute through their core activities, and we ask companies everywhere to assess their impact, set ambitious goals and communicate transparently about the results".

Table 1. Concepts from the UN Agenda 2030 and SDG framework.

\begin{tabular}{ccc}
\hline Source & Core Concept & References \\
\hline Agenda 2030 & Announced commitment. & {$[54]$} \\
\hline SDG 17 & $\begin{array}{c}\text { Stakeholders engagement, partnerships. } \\
\text { Voluntary commitment. } \\
\text { Efficient communication. }\end{array}$ & {$[48,55]$} \\
\hline Global indicator framework & $\begin{array}{c}\text { Measurability of performance. } \\
\text { Data collection and management. }\end{array}$ & {$[49,56]$} \\
\hline
\end{tabular}


The system's stakeholders are government (central government and authorities), academia (education and research institutions), and industry (private sector). These stakeholders have been identified based on their significant roles and proven involvement in the SDG integration process.

\section{Step 2: Define requirements.}

To gain insight on the inclusion of SDGs as a vision, goals, and targets in value chains, the needs must be established as requirements in the developed framework. The needs are from step 1: declared commitment from all involved stakeholders, communication about the SDGs within the NSVC, and measuring the performance of its application. The concept of performance measurability, with its associated data collection, is applied in companies as key performance indicators (KPIs). It provides businesses with a means of measuring progress toward achieving set objectives. The integration of SDGs within the operational structure of a value chain should begin with identifying the data for performance monitoring in accordance with the global indicators associated with the respective SDG. Environmental impact assessment methods and sustainability performance assessment methods that already are commonly applied have high relevance to SDGs, with growing levels of integration between these methods and SDG-required measurements [51]. Industrial systems are required to be flexible and adaptable to change, a capacity that is determined by their level of structural and operational complexity [52]. A complex system would react to any change in its static structure with unpredictable, counterintuitive behavioral dynamics [53]. Complexity mitigation requires consistent, clear communication and strong stakeholder engagement [54]. SDG integration carries substantial changes in the system that will face points of resistance versus drives and stimulants. For the developed framework to address SDG integration objectively, it must investigate the complexity level in the system. In Table 2, we present needs and requirements as SE concepts and terms.

Table 2. SE concepts $[23,57]$ as required criteria in the developed framework.

\begin{tabular}{cc}
\hline Systems Engineering Concepts & Criteria for Framework Development \\
\hline Problem-oriented & Insight on SDG integration into the NSVC \\
\hline Product life cycle & Whole value chain as one system \\
\hline Stakeholder engagement & Voluntary commitments, SDG communication \\
\hline Complexity analysis & Response of system's structure to SDG insertion \\
\hline Data management and reasoning & Performance measurability, SDGs as corporate KPIs \\
\hline Validation & Supported by empirical findings.
\end{tabular}

Step 3: Specify performance.

The main consideration in this step is to specify how the SDG integration process will flow and how it will be carried out by the involved parties. From previous steps, a conceptual model for the SDG integration process evolved from the needs, requirements, and systems stakeholders (see Figure 2). The developed framework must be:

1. Representative of reality, reflecting the SDG integration process as carried out by involved stakeholders in a logical sequence and with respect to the timeline of events.

2. Evidence-based, describing the appearance of the SDGs in official communications, documents, and declared policies.

3. Capable of including the NSVC as a whole system, presenting highlighted barrier factors and support factors. 


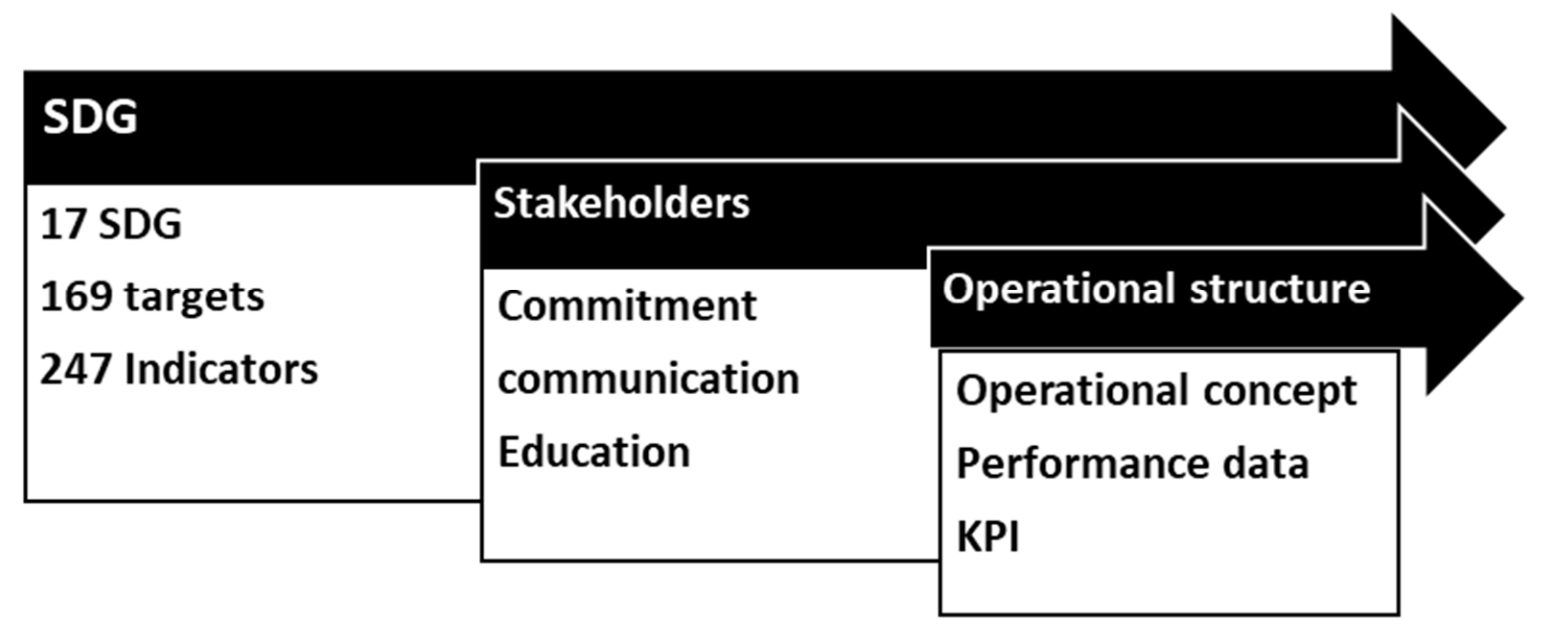

Figure 2. Conceptual scheme for SDG integration into value chains.

\section{Step 4: Analyze and Optimize.}

To analyze the outcomes of steps 1-3, we looked at the NSVC system, including its subsystems. The SDG integration process is a top-down approach that starts with commitment and relies on knowledge, education, and communication flow among stakeholders. Therefore, seeking evidence to validate the framework can be achieved by reviewing the sustainability reports coming out of the industry. In this step, we aim to define which factors drive SDG integration within the NSVC. Reviewing the empirical findings on the SDGs in Norway and in the NSVC can define insight factors that can drive the merge between the SDGs and NSVC or other factors that will add to the complexity of this integration.

\section{Step 5: Design and Solve.}

This step aimed to design a framework solution that can allow for gaining holistic multi-stakeholders insight. Elements defined in the previous steps were deployed in a conceptual structure (see Table 3).

Table 3. Summary of the conceptual variables as elaborated by the authors.

\begin{tabular}{|c|c|}
\hline Variables & Reasoning \\
\hline Commitment & $\begin{array}{l}\text { Agenda 2030: Top governmental commitment. } \\
\text { SDG: Voluntary stakeholders' commitment. }\end{array}$ \\
\hline Complexity & $\begin{array}{l}\text { Obstacles, incentives, and enablers for the integration of a } \\
\text { global agenda. }\end{array}$ \\
\hline Communication & $\begin{array}{l}\text { SDG 17: Creating partnerships through communication. } \\
\text { Flow of information to support the system and } \\
\text { SDG integration. }\end{array}$ \\
\hline System's Data & $\begin{array}{l}\text { System's ability to measure performance in relation to SDGs } \\
\text { and provide supporting data. }\end{array}$ \\
\hline Sustainability KPI & Optimum form of a goal's integration in a company's strategy. \\
\hline
\end{tabular}

The proposed framework is composed of five steps, summed in the acronym (TCSAS) (see Figure 3), to be applied on the value chain as a targeted system. First step: Review the status of the existing commitments to the SDGs by the system's stakeholders. It is important to identify where the system is located, between governmental commitment to the SDGs and the voluntary commitment by academia and industrial sectors. Second step: A complexity analysis of the system to define obstacles and drives for SDG integration. The system's complexity will be approached by reviewing the system's three dimensions: structure, dynamic (operations), and sociopolitical $[58,59]$. Third step: Identify the sys- 
tem's communication channels between the stakeholders and the operational structure (company/corporation). Highlight the presence of the SDG in stakeholders' communications and in the operational responding communications. Fourth step: Align the system's existing data pool with the SDG and its associated global indicators framework. Identify existing data that serves SDG indicators and the needed measurable parameters to reflect the system's SDG progress track. Fifth step: How SDGs are being adopted as key performance indicators within the culture and practice of the company. Sustainability KPIs must be fit for corporate reporting and public communication on SDGs, rising from a supportive body of knowledge and cutting-edge scientific findings.

Tag system's location on the commitment map

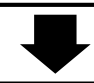

Complexity analysis for the system's structure

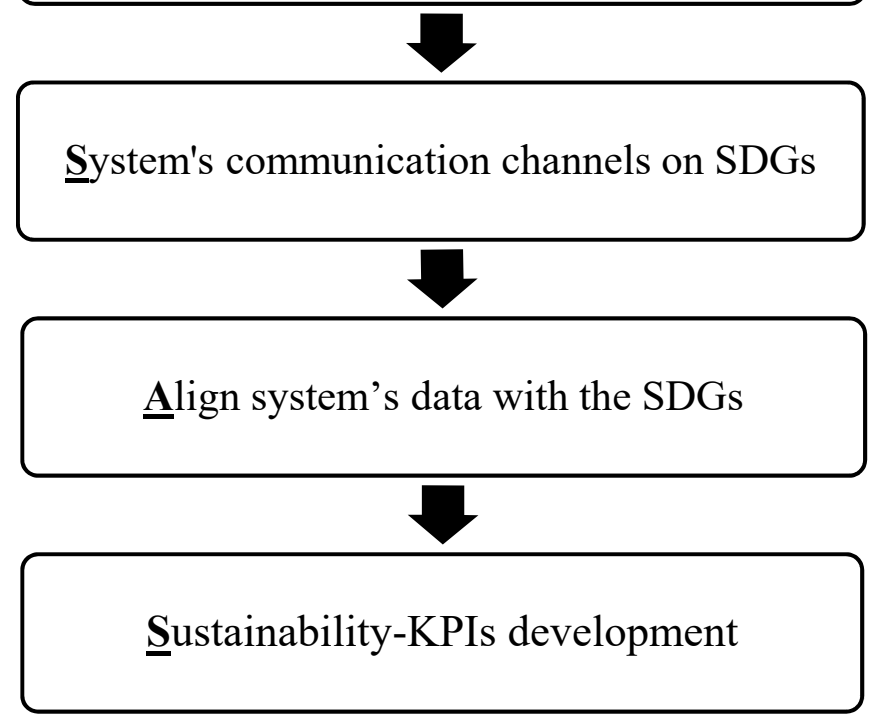

Figure 3. Framework to gain insight on SDG integration into value chains (TCSAS).

\section{Step 6: Verify and Test.}

We applied each step of the TCSAS framework on the NSVC and matched the concepts with the relevant empirical findings obtained on the SDGs from stakeholders' communications (Section 2.3).

\subsection{Empirical Findings Acquisition}

An empirical study was conducted on the basis of a critical discourse analysis (CDA) [60] of publicly available reports from the NSVC's stakeholders-government, academia, and industry-in relation to the SDG between 2016 and 2020. Governmental documents, corporate reports, published articles, and official websites (Table 4) were selected as units of analysis. The choice of units of analysis was based on common criteria, which included:

- The presence of SDGs in the system's communications.

- Statements of commitment to SDG implementation.

- Data-supported indicators on performance related to SDGs. 
Table 4. Selected NSVC stakeholders for the scope of this study.

\begin{tabular}{|c|c|c|}
\hline & Stakeholders & Empirical Findings on SDG \\
\hline \multirow{3}{*}{ Government } & Top Government & Commitment: 2021 voluntary national review [61] \\
\hline & Ministry of Foreign Affairs & Follow-up Agenda 2030 report [61] \\
\hline & Seafood Norway (national association) & Aquaculture 2030 report [62] \\
\hline \multirow{9}{*}{ Industry } & Lerøy Seafood Group & Annual sustainability report [63] \\
\hline & MOWI & Annual sustainability report [64] \\
\hline & Grieg Seafood & Annual sustainability report [65] \\
\hline & Nova Sea & Annual sustainability report [66] \\
\hline & SALMAR & Annual sustainability report [67] \\
\hline & Cargill Aqua Nutrition & Annual sustainability report [68] \\
\hline & BIOMAR & Annual sustainability report [69] \\
\hline & Cermaq & Sustainability web page [70] \\
\hline & Skretting & Annual sustainability report [71] \\
\hline \multirow{10}{*}{ Academia } & NTNU (Norwegian University of Science and Technology) & SDG education and research [72] \\
\hline & UIB (University of Bergen) & $\begin{array}{c}\text { Official SDG } 14 \text { (Life below water) hub for United } \\
\text { Nations Academic Impact and the International } \\
\text { Association of Universities [73] }\end{array}$ \\
\hline & UIO (University of Oslo) & SDG are frequently mentioned on website [74] \\
\hline & NMBU (Norwegian University of Life Sciences) & SDGs are mentioned on website [75] \\
\hline & University of Tromsø-The Arctic University of Norway & SDG research and education event [76] \\
\hline & University of Stavanger & SDG education and research projects [77] \\
\hline & University of Agder & SDG education and research [78] \\
\hline & University of South-Eastern Norway & SDG education and research [79] \\
\hline & OsloMet-Oslo Metropolitan University & SDG education and research [80] \\
\hline & Nord University & SDG research [81] \\
\hline
\end{tabular}

We reviewed the Norwegian government's official follow-up report on the SDGs, which is publicly available on the ministry of foreign affairs website.

In a list published by slamonbuisness.com for the largest salmon producers in 2019, classified according to their production size in kilotons per year, 11 out of the top $20 \mathrm{com}$ panies were Norwegian. We reviewed these 11 companies and found that four of them do not have the practice of annual sustainability reports, and one company has no mention of the SDGs. The selected six companies are the largest producers in Norway and do have annually released sustainability reports. Furthermore, because we are focusing on the entire value chain, we included the salmon-feed producers in Norway with the reviewed companies. We looked for the largest salmon-feed producers. Based on experts' advice, we identified the four major feed corporations, one of which is also a salmon producer, and all four were selected for review. Norway currently has 10 universities, 8 university colleges and 5 scientific colleges owned by the state. We reviewed the Norwegian universities websites, excluding colleges and specialized education institutes by conducting a search on the universities webpages through the use of their online search engine. The following search words was used: Sustainable development goals, SDG, Agenda 2030.

Findings categorized and detailed under the TCSAS five steps will be presented in support of the TCSAS framework validation. 


\subsection{Framework Application}

First step: Tag the Norwegian salmon value chain on the SDG stakeholders' commitment map.

There is a clear governmental commitment toward the SDGs since their announcement in 2015. "At a time when we need more, not less, global cooperation, the 2030 Agenda for Sustainable Development is the roadmap ensures everyone wins, even at the national level"- quote from Norwegian Prime Minister Erna Solberg at UN General Assembly 2019. There is a Norwegian governmental follow-up on the progress of the SDG transitional process [61]. At the industrial level (private sector), the national association for seafood producers in Norway reported "aiming to contribute" to the progress of SDG achievement [82]. Annual sustainability reports from major companies in the NSVC mentioned the SDGs and presented the company's efforts toward their progress [69]. In 2016, corporate leaders and CEOs of the salmon industry in Norway and 12 other countries included the SDGs as part of the Global Salmon Initiative (GSI), with a clear voluntary commitment to the SDGs [83]. A National Committee for Agenda 2030 (SDG Norway) in higher education was formed in 2018 to strengthen the role of universities as relevant actors in the global endeavor raised by Agenda 2030 [73]. Evidence of commitment to the SDGs was found in the system's three most involved stakeholders: government, academia, and industry (see Figure 4).

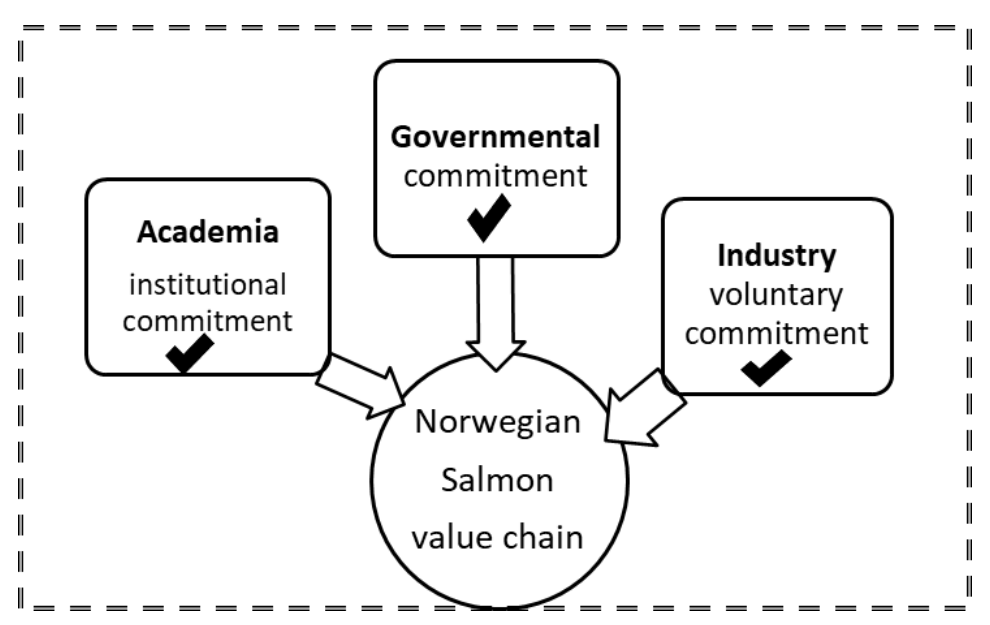

Figure 4. Stakeholders' commitment to SDGs.

Second step: Complexity analysis of the system's structure.

By reviewing the NSVC's structure [24,28,84-86], we identified certain structural, dynamic, and sociopolitical elements in the system that might add to or reduce its level of complexity in relation to SDG integration (see Table 5).

Table 5. NSVC system's complexity in relation to SDGs.

\begin{tabular}{ccccc}
\hline Complexity Category & Complexity Element & Adding & Reducing & Reason \\
\hline & $\begin{array}{c}\text { Geographical } \\
\text { expansion }\end{array}$ & 0 & 1 & $\bullet \quad \begin{array}{l}\text { International perspective, raise interest } \\
\text { in SDG. }\end{array}$ \\
\cline { 2 - 5 } Structural & $\begin{array}{c}\text { Multiple operational } \\
\text { subsystems }\end{array}$ & 1 & 0 & $\bullet \quad \begin{array}{l}\text { Require continuous/extended control } \\
\text { and data acquisition. }\end{array}$ \\
\cline { 2 - 5 } & $\begin{array}{c}\text { Environment } \\
\text { (marine and land) }\end{array}$ & 1 & 1 & $\begin{array}{l}\text { Norway's environment is regulated } \\
\text { and monitored. } \\
\text { Raw material from multiple countries. }\end{array}$ \\
\hline
\end{tabular}


Table 5. Cont

\begin{tabular}{|c|c|c|c|c|}
\hline Complexity Category & Complexity Element & Adding & Reducing & Reason \\
\hline \multirow[b]{2}{*}{ Dynamic } & $\begin{array}{l}\text { Research and } \\
\text { development }\end{array}$ & 0 & 1 & $\begin{array}{l}\text { - Persevere research, well-funded, } \\
\text { institutional. } \\
\text { - Several challenges still under research } \\
\text { for solutions. }\end{array}$ \\
\hline & $\begin{array}{l}\text { Large corporations } \\
\text { with centralized } \\
\text { decision making }\end{array}$ & 0 & 1 & $\begin{array}{l}\text { Embracing change by top } \\
\text { management can guarantee } \\
\text { compliance by the entire value chain. } \\
\text { Gives more value for voluntary } \\
\text { commitment to SDGs. }\end{array}$ \\
\hline Socio-political & $\begin{array}{l}\text { Societal support for } \\
\text { sustainability }\end{array}$ & 0 & 1 & $\begin{array}{l}\text { - } \quad \text { Governmental commitment to SDGs. } \\
\text { Social interest in environmental } \\
\text { wellbeing and sustainability. }\end{array}$ \\
\hline
\end{tabular}

Third step: System's communication channels.

The SDGs are present in stakeholders' communications and the associated literature. The NSVC information pool is nourished by input from institutions that are committed to the SDGs. This input is communicated through the channels of published research literature and education discourse [87] for professionals who serve the industry. The engagement of a broad range of researchers in scholarly discussions about SDG implementation is central [88]. Expanding the discussion to involve more groups of interest in the NSVC can be described as an area for further development. The system is regulated by governmental institutions that are committed to the SDGs; this is clearly communicated in the media, official websites, and reports. In addition, the Norwegian practices of science-industry platforms, conferences, and consortiums are a significant channel for communications about the SDGs. The practice of releasing annual corporate sustainability reports is common among Norwegian seafood corporations. Reports communicated to the public on company websites contribute to transparency and collective knowledge about the SDGs. Annual corporate sustainability reports can reflect the system's responsiveness to the SDGs, a feedback loop of information from companies to the SDG-committed society about the integration of SDGs in the operational structure of the NSVC.

Fourth step: Align the system's data with the global indicator framework.

The NSVC's available data is systemically gained through a well-established methodology. Reviewed reports, published information, and statistics display the system's data acquisition capabilities, which can be described as high. The system's existing data in relation to the SDGs can be categorized as social, environmental, and economic. Official statistics on the salmon industry are publicly available on the Norwegian statistics bureau website [31]. The NSVC has an environmental database that can cover many of the SDG requirements; the methodology of life-cycle assessment (LCA) has been a common practice in this industry to assess environmental impacts [89]. Scientific research and data acquisition on salmon production and sustainability is a continuous endeavor in Norwegian universities $[28,89,90]$. Besides the environmental data, there are data on material-efficient utilization, food, nutrients, the societal contribution of employment, gender equality, and revenue, all of which were presented in the reviewed corporate sustainability reports [54-63].

Fifth step: Sustainability key performance indicators (KPIs), obtained from SDGs.

A key performance indicator (KPI) is a measurable value that demonstrates how effectively a company is achieving objectives. Companies present their revenue, number of jobs, gender balance in employment, material utilization efficiency, environmental impact, and related practices as KPIs of the company's progress. The NSVC's major companies release annual sustainability reports that reflect the continuous search for 
more KPIs on all aspects of production and perspectives of sustainability. The reviewed corporate sustainability reports from the NSVC showed several SDG-driven KPIs. The reported KPIs reflected companies' efforts and achievements on protecting the ocean, community empowerment, responsible production, climate action, and partnerships for SDG achievement. Adopting the SDGs with a clear commitment, including using their indicators as KPIs and referring to them in annual corporate sustainability reports, is a common feature of the NSVC. However, there are different levels of SDG inclusion as KPIs between the different companies, ranging from total integration and usage of SDG terminology, icons, and associated indicators to limited mentions [64,69,91-93]. The reviewed corporate sustainability reports indicate that SDGs are a thriving trend in the NSVC's corporate reporting and communication culture (see Table 6).

Table 6. Examples of KPIs derived from SDGs found in the reviewed reports.

\begin{tabular}{|c|c|c|c|}
\hline Company & Reference & Examples of: KPIs & SDG \\
\hline Lerøy & report [63] & $\begin{array}{l}\text { - } 50 \% \text { reduction in the use of non-recyclable plastic } \\
\text { by } 2024 \\
\text { - } \quad \text { Participation in multi-stakeholder initiatives } \\
\text { - } \quad \text { Food waste reduction }\end{array}$ & $\begin{array}{l}\text { Goal } 14 \\
\text { Goal } 17 \\
\text { Goal } 12\end{array}$ \\
\hline MOWI & report [64] & $\begin{array}{l}\text { - } \quad \text { Energy use and GHG emissions } \\
\text { - } \quad \text { Percentage of sites with minimum benthic Impact. } \\
\text { - } \quad \text { Training on diversity and equal rights }\end{array}$ & $\begin{array}{l}\text { Goal } 12 \\
\text { Goal } 14 \\
\text { Goal } 8\end{array}$ \\
\hline Grieg & report [65] & $\begin{array}{l}\text { - } \quad \text { Minimum usage of hydrogen peroxide treatment } \\
\text { - } \quad \text { Carbon footprint reduction } \\
\text { - }\end{array}$ & $\begin{array}{l}\text { Goal } 14 \\
\text { Goal } 13 \\
\text { Goal } 12\end{array}$ \\
\hline Nova Sea & report [66] & $\begin{array}{ll}\text { - } & \text { Zero antibiotics usage } \\
\text { - } & \text { Reducing } \mathrm{Co} 2 \text { emission per } \mathrm{kg} \text { of salmon }\end{array}$ & $\begin{array}{l}\text { Goal } 14 \\
\text { Goal } 13\end{array}$ \\
\hline SALMAR & report [67] & $\begin{array}{l}\text { - } \quad \text { Higher } 12 \text { month rolling survival rate } \\
\text { - } \quad \text { Omega-3 production }\end{array}$ & $\begin{array}{c}\text { Goal } 14 \\
\text { Goal } 3\end{array}$ \\
\hline Cargill & report [68] & $\begin{array}{l}\text { - Increase resource efficiency of farmed fish } \\
\text { - } \quad 35 \% \text { trimming of marine ingredients }\end{array}$ & $\begin{array}{l}\text { Goal } 14 \\
\text { Goal } 12\end{array}$ \\
\hline BIOMAR & report [69] & $\begin{array}{l}\text { - } \quad \text { Fish feeds are } 50 \% \text { circular and restorative by } 2030 \\
\text { - } 20 \% \text { reduction per kg of feed by } 2020\end{array}$ & $\begin{array}{l}\text { Goal } 14 \\
\text { Goal } 2\end{array}$ \\
\hline Cermaq & website [70] & $\begin{array}{l}\text { - } \quad \text { Increasing share of plant-based feed } \\
\text { - } \quad \text { Cut GHG emissions by } 35 \% \text { by } 2030\end{array}$ & $\begin{array}{l}\text { Goal } 14 \\
\text { Goal } 13\end{array}$ \\
\hline Skretting & report [71] & $\begin{array}{l}\text { - Operational actions to reduce impact through KPIs } \\
\text { - } 50 \% \text { reduction in antibiotic usage }\end{array}$ & $\begin{array}{l}\text { Goal } 13 \\
\text { Goal } 14\end{array}$ \\
\hline
\end{tabular}

\section{Discussion}

The six-step method is a structured approach based on a logical systematic order to systemic challenges. The developed TCSAS framework came about as a result of the SE approach of the six-step method application. By applying the TCSAS framework to the NSVC case, we can see that the system's host country's official government's commitment to sustainability - in general, and to the UN SDGs in particular-is driven to embrace the SDGs within the operational structure of the system. The heavy influence of the governmental stakeholder in shaping the vision for development and related policies [89] was deployed in favor of SDG integration. A lack of political will is not found to be a roadblock between aquaculture and SDG implementation in the NSVC, in contrast to 
previous findings [94]. The TCSAS framework relied on understanding the value chain's structure, operational dynamics, and sociopolitical reality as a prerequisite to identify its complexity and adaptability to the integration of SDGs. In this study, the NSVC is seen as a moderate-complexity system in its SDG relation, with more complexity-reducing than complexity-adding factors. The geographical expansion of the NSVC over several countries is a significant consideration, starting from where the basic raw material is produced and then imported to the aquaculture production sites in Norway all the way to the product export destinations all over the globe. This international presence gives more importance to the global perspective of sustainability and the SDGs. The NSVC is structured around salmon feed production from plant material and marine material, then progressing to salmon-farming in sea cages in the marine environment. Clearly, both environments-land and marine-are impacted by this industry and must be included in any sustainability endeavor. Findings of the academic stakeholder (universities) point out that the NSVC is supported by continuous research and development, making it a dynamic system that can embrace change with a high capacity for adaptation despite the presence of certain complexity-adding factors. Responsive communication between the system's stakeholders and system's operational structure is the main channel for the SDGs to flow into the system. The SDGs' appearance in stakeholders' communications, the literature, educational discourse, websites, reports, etc., is indirectly inviting a response from the industry on the issue of SDG implementation. The empirical findings showed evidence of voluntary commitment to SDGs in the industrial private sector. A milestone example is the global salmon initiative [83]. Academia is considered by this study as a major stakeholder in embracing the SDGs; the findings confirmed that Norwegian universities are engaged in the process of SDG integration. Most of the scientific research on the NSVC is taking place in universities, where most of NSVC's skilled workforce is being educated. The SDGs are frequently mentioned on universities' official websites and presented within education programs, sustainability projects, and in their published research work. "It is vital for Norway to have a national action plan for the Sustainable Development Goals and only natural for academia to inhabit a key role by contributing with research-based knowledge and critical thinking on the goals," says Vice-Rector Annelin Eriksen at the 2019 National SDG Conference, University of Bergen. The sustainability reporting from a global value chain must have the qualities of being internationally directed, considerate of product life cycle from source to sink, and holistically covering all sustainability criteria. Adopting SDG in NSVC's communications provides globally understood terms to describe NSVC's sustainability endeavors, this advantage motivates for further inclusion of the SDG. Moreover, the presence of SDGs in the sustainability communications of global value chains is becoming highly anticipated [95]. The occurrence of import/export operations and the expansion of the NSVC over several countries creates a need for international common ground and terminology for communicating sustainability performance. Defining the coordinates of where the local system is standing relative to the global agenda and highlighting the points of intersection will upgrade the communication and performance on sustainability within the corporate culture. The existing corporate practices, considerate of local environmental protection and societal and economical welfare, are also serving collective global sustainability. The communication on SDGs from companies to other stakeholders requires providing relevant performance data. The purpose of including the SDGs in corporate culture and practices is not only as a vision for the future but also as a systemic data-based framework for development. The corporate practice of releasing an annual sustainability report with supporting data to the claims of achievement to the public is seen by this study as a cornerstone in the SDG integration process. Communicating sustainability information from companies to system's stakeholders who are voluntarily committed to the SDGs, might lead to mentioning the company's commitment to SDGs in its mission statement or general policy. The question of what benefits might interest the companies in committing to SDGs is a start point to understand how UN SDGs can introduce new concepts that will improve the system's local reality in relation to sustainability. 
Such a perspective might raise the awareness of responsibility toward global sustainability, both at the corporate and societal levels. The SDGs' general perspective for a sustainable value chain is that it is profitable throughout all its stages and provides broad benefits for society with a positive or neutral impact on the environment. SDG-guided value chains must adopt the full life-cycle perspective, expanding the focus from basic raw material obtainment to the endpoint of the product, including its processing, supply, delivery, and waste. Companies are key functional structures in the process of integrating the SDGs into value chains. Larger companies (corporations) have larger sustainability-related impacts that are spatially spread over different countries. Corporate activities severely affect the present and critically impact the future, and for that reason, corporate sustainability is necessary for the long-term sustainable development of the economy and society [96]. There is a general agreement that a value chain's success and survival require consideration for sustainability [97]. A value chain's economic, environmental, and social performance may significantly benefit from integrating SDGs into their standard business practices. Integrating SDGs into corporate strategy can be achieved by developing the most appropriate KPI system to create a strategic alignment with the global indicators framework [98]. Developing a KPI that serves the SDGs within the value chain is a collective task that requires efficient communication, partnerships, empowerment of the involved, and a high level of commitment [99]. The communication on SDGs is more prominent in companies with high business volume and regular release of sustainability reports on their official websites [100]. This correlation is clearly observed in the NSVC.

\section{Conclusions}

The suggested framework (TCSAS) managed to provide system insight on the integration process of SDGs within the NSVC. Communication on SDGs by NSCV stakeholders progresses into responsive, data-supported reporting from the operational structure on its status of commitment and performance in relation to the SDGs. Internationally operating value chains have an interest in embracing SDGs into their sustainability endeavors due to the SDGs' global nature. This study showed that after six years from the declared Norwegian governmental commitment to the SDGs, the SDGs were found to be present in the largest companies in the NSVC, as evidenced in their issued annual sustainability reports. This reflects the relative efficiency of the top-down approach. The academic institutions are creating a pool of knowledge about the SDGs' value, which is accessible by the industry. We see that the SDGs' optimum form of integration in an industrial system materializes as strategically adopted measurable key performance indicators (KPIs) associated with specific SDGs.

\section{Limitations and Future Research}

The level of SDG integration within the NSVC will progress further with time and gain more depth and breadth. There is the potential for a feedback loop of useful practical insights on the SDG integration process within the NSVC to the global stakeholders of the UN SDGs and other global value chains. It can carry new perspectives to serve SDG implementation in other value chains. This study investigated the system's available communication channels on SDGs without much focus on the "Status of Dialectic" within the system around the SDGs. Future research should be done on the adoption of each of the 17 SDGs and investigate their specific challenges. The framework proposed in this paper could be applied to other industries to gain insight into their SDG integration processes.

Author Contributions: The article was primarily written and conceptualized by M.A., then reviewed by E.S.B., who supervised the research and edited the article as part of a Ph.D. research project. T.R. reviewed the article and gave significant input to the discussion about the NSVC. All authors have read and agreed to the published version of the manuscript.

Funding: This research received no external funding.

Institutional Review Board Statement: Not applicable. 
Informed Consent Statement: Not applicable.

Data Availability Statement: Not applicable.

Acknowledgments: All required resources for this study were provided by The Norwegian University of Science and Technology (NTNU), acknowledged with appreciation and gratitude.

Conflicts of Interest: The authors declare no conflict of interest.

\section{References}

1. Hopwood, B.; Mellor, M.; O’Brien, G. Sustainable development: Mapping different approaches. Sustain. Dev. 2005, 13, 38-52. [CrossRef]

2. Pérez-Peña, M.d.C.; Jiménez-Garcíaet, M.; Ruiz-Chico, J.; Peña-Sánchez, A.R. Analysis of Research on the SDGs: The Relationship between Climate Change, Poverty and Inequality. Appl. Sci. 2021, 11, 8947. [CrossRef]

3. UN. Governmental Document A/RES/70/1. Transforming Our World: The 2030 Agenda for Sustainable Development; General Assemply in Sep.2015: United Nations Headquarters in New York; United Nations: New York, NY, USA, 2015.

4. Warchold, A.; Pradhan, P.; Kropp, J.P. Variations in sustainable development goal interactions: Population, regional, and income disaggregation. Sustain. Dev. 2021, 29, 285-299. [CrossRef]

5. Bengtsson, M.; Alfredsson, E.; Cohen, M.; Lorek, S.; Schroeder, P. Transforming systems of consumption and production for achieving the sustainable development goals: Moving beyond efficiency. Sustain. Sci. 2018, 13, 1533-1547. [CrossRef] [PubMed]

6. Palmer, E.; Burton, R.; Haskins, C. A Systems Engineering Framework for Bioeconomic Transitions in a Sustainable Development Goal Context. Sustainability 2020, 12, 6650. [CrossRef]

7. Olofsson, L.; Mark-Herbert, C. Creating Shared Values by Integrating UN Sustainable Development Goals in Corporate Communication-The Case of Apparel Retail. Sustainability 2020, 12, 8806. [CrossRef]

8. Pedersen, C.S. The UN Sustainable Development Goals (SDGs) are a Great Gift to Business! Procedia CIRP 2018, 69, 21-24. [CrossRef]

9. Banerjee, A.; Murphy, E.; Walsh, P. Perceptions of Multistakeholder Partnerships for the Sustainable Development Goals: A Case Study of Irish Non-State Actors. Sustainability 2020, 12, 8872. [CrossRef]

10. Avelar, A.B.A.; Silva-Oliveira, K.D.d.; Pereira, R.d.S. Education for advancing the implementation of the Sustainable Development Goals: A systematic approach. Int. J. Manag. Educ. 2019, 17, 100322. [CrossRef]

11. El-Jardali, F.; Ataya, N.; Fadlallah, R. Changing roles of universities in the era of SDGs: Rising up to the global challenge through institutionalising partnerships with governments and communities. Health Res. Policy Syst. 2018, 16, 38. [CrossRef]

12. Patole, M. Localization of SDGs through disaggregation of KPIs. Economies 2018, 6, 15. [CrossRef]

13. Closs, D.J.; Speier, C.; Meacham, N. Sustainability to support end-to-end value chains: The role of supply chain management. J. Acad. Mark. Sci. 2011, 39, 101-116. [CrossRef]

14. Pradhan, P.; Costa, L.; Rybski, D.; Lucht, W.; Kropp, J.P. A Systematic Study of Sustainable Development Goal (SDG) Interactions. Earth's Future 2017, 5, 1169-1179. [CrossRef]

15. Bryan, B.A.; Hadjikakou, M.; Moallemi, E.A. Rapid SDG progress possible. Nat. Sustain. 2019, 2, 999-1000. [CrossRef]

16. Rendtorff, J.D. Sustainable development goals and progressive business models for economic transformation. Local Econ. 2019, 34, 510-524. [CrossRef]

17. Sachs, J.D.; Schmidt-Traub, G.; Mazzucato, M.; Messner, D.; Nakicenovic, N.; Rockström, J. Six transformations to achieve the sustainable development goals. Nat. Sustain. 2019, 2, 805-814. [CrossRef]

18. Fleming, A.; Wise, R.M.; Hansen, H.; Sams, L. The sustainable development goals: A case study. Mar. Policy 2017, 86, 94-103. [CrossRef]

19. Swain, R.B. A Critical Analysis of the Sustainable Development Goals. In Handbook of Sustainability Science and Research; Leal Filho, W., Ed.; Springer International Publishing: Cham, Switzerland, 2018; pp. 341-355.

20. Kapurch; Stephen, J. (Eds.) NASA Systems Engineering Handbook; Diane Publishing: Collingdale, PA, USA, 2010.

21. Brooks, I.; Longhurst, J.; Kossmann, M.; Odeh, M. Implementing the United Nations Sustainable Development Goals for the Systems Engineering of Multinational Corporations. INCOSE Int. Symp. 2018, 28, 1399-1411. [CrossRef]

22. Yang, L.; Cormican, K. The Crossovers and Connectivity between Systems Engineering and the Sustainable Development Goals: A Scoping Study. Sustainability 2021, 13, 3176. [CrossRef]

23. INCOSE. Vision 2025. 2021. Available online: https://www.incose.org/about-systems-engineering/se-vision-2025 (accessed on 10 March 2021).

24. Bergesen, O.; Tveterås, R. Innovation in seafood value chains: The case of Norway. Aquac. Econ. Manag. 2019, 23, 292-320. [CrossRef]

25. Koesling, M.; Kvadsheim, N.P.; Halfdanarson, J.; Emblemsvåg, J.; Rebours, C. Environmental impacts of protein-production from farmed seaweed: Comparison of possible scenarios in Norway. J. Clean. Prod. 2021, 307, 127301. [CrossRef]

26. Hersoug, B. The greening of Norwegian salmon production. Marit. Stud. 2015, 14, 16. [CrossRef]

27. Seung, C.; Kim, D.H. Examining Supply Chain for Seafood Industries Using Structural Path Analysis. Sustainability 2020, $12,2061$. [CrossRef] 
28. Abualtaher, M.; Bar, E. Systems Engineering Approach to Food Loss Reduction in Norwegian Farmed Salmon Post-Harvest Processing. Systems 2020, 8, 4. [CrossRef]

29. Statistics_Norway_Official_Statistics. First-Hand Value of Salmon in 2019. Released in 2020. Available online: https://www.ssb. no/en/jord-skog-jakt-og-fiskeri/statistikker/fiskeoppdrett/aar-forelopige (accessed on 21 July 2021).

30. Gudrun Olafsdottir, S.M.; Roger, R.; David, C.; Ingunn, Y.R.; Gudbrandsdottir, M.T.; Alistair, L.; Sigurdur, G.B. Valumics-Report: Overview of the Farmed Salmon Value Chain. 2020. Available online: https://valumics.eu/wp-content/uploads/2019/10/ Valumics-AES-vol44-2-sept2019.pdf (accessed on 21 August 2021).

31. Statistics-Norway. Official Statistics about Norwegian Society 2020. Available online: https://www.ssb.no/en (accessed on 23 October 2021).

32. Aas, T.S.; Ytrestøyl, T.; Aasgaard, T. Utilization of feed resources in the production of Atlantic salmon (Salmo salar) in Norway: An update for 2016. Aquac. Rep. 2019, 15, 100216. [CrossRef]

33. Abolofia, J.; Asche, F.; Wilen, J.E. The Cost of Lice: Quantifying the Impacts of Parasitic Sea Lice on Farmed Salmon. Mar. Resour. Econ. 2017, 32, 329-349. [CrossRef]

34. Aronsen, T.; Ulvan, E.M.; Næsje, T.F.; Fiske, P. Escape history and proportion of farmed Atlantic salmon Salmo salar on the coast and in an adjacent salmon fjord in Norway. Aquac. Environ. Interact. 2020, 12, 371-383. [CrossRef]

35. Jensen, Ø.; Dempster, T.; Thorstad, E.B.; Uglem, I.; Fredheim, A. Escapes of fishes from Norwegian sea-cage aquaculture: Causes, consequences and prevention. Aquac. Environ. Interact. 2010, 1, 71-83. [CrossRef]

36. Cashion, T.; Hornborg, S.; Ziegler, F.; Hognes, E.S. Tyedmers, Review and advancement of the marine biotic resource use metric in seafood LCAs: A case study of Norwegian salmon feed. Int. J. Life Cycle Assess. 2016, 21, 1106-1120. [CrossRef]

37. Ellingsen, H.; Aanondsen, A. Environmental impacts of wild caught cod and farmed salmon-A comparison with chicken. Int. J. Life Cycle Assess. 2006, 11, 60-65. [CrossRef]

38. Hognes, E.S.; Nilsson, K.; Sund, V.; Ziegler, F. LCA of Norwegian Salmon Aquaculture 2012; SINTEF Fisheries and Aquaculture: Trondheim, Norway, 2012; p. 41.

39. Philis, G.; Gracey, E.O.; Gansel, L.C.; Fet, A.M.; Rebours, C. Comparing the primary energy and phosphorus consumption of soybean and seaweed-based aquafeed proteins A material and substance flow analysis. J. Clean. Prod. 2018, 200, 1142-1153. [CrossRef]

40. Ytrestøyl, T.; Aas, T.S.; Asgard, T. Utilisation of feed resources in production of Atlantic salmon (Salmo salar) in Norway. Aquaculture 2015, 448, 365-374. [CrossRef]

41. Aas, T.S.; Åsgård, T.E. Estimated Content of Nutrients and Energy in Feed Spill and Faeces in Norwegian Salmon Culture. Nofima Rapp. 2017. Available online: https://nofima.brage.unit.no/nofima-xmlui/handle/11250/2452167 (accessed on 15 September 2021).

42. Abualtaher, M.; Bar, E.S. Food-Loss Control at the Macronutrient Level: Protein Inventory for the Norwegian Farmed Salmon Production System. Foods 2020, 9, 1095. [CrossRef]

43. Rustad, T. Maximising the Value of Marine by-Products (Chapter Physical and Chemical Properties of Protein Seafood by-Products); Woodhead Publishing in Food Science, Technology and Nutrition; Shahidi, F., Ed.; CRC Press Woodhead Publ.: Boca Raton, FL, USA; Cambridge, UK, 2007.

44. Fet, A.M. Systems engineering methods and environmental life cycle performance within ship industry. PhD Thesis, Doktor Ingeniøravhandling, Department of Thermal Energy and Hydro Power, NTNU, Trondheim, Norway, 1997.

45. Fet, M.A. Environmental management tools and their application: A review with reference to case-studies. In Book Knowledge for Inclusive Development: International Series on Technology Policy and Innovation; Conceição, P., Gibson, D.V., Heitor, M.V., Sirilli, G., Veloso, F., Eds.; Greenwood Publishers: Fairfield County, CT, USA, 1999; pp. 449-464.

46. Maya Sopha, B.; Magerholm Fet, A.; Maria Keitsch, M.; Haskins, C. Using systems engineering to create a framework for evaluating industrial symbiosis options. Syst. Eng. 2010, 13, 149-160. [CrossRef]

47. Magerholm Fet, A.; Schau, E.M.; Haskins, C. A framework for environmental analyses of fish food production systems based on systems engineering principles. Syst. Eng. 2010, 13, 109-118. [CrossRef]

48. Stibbe, D.; Prescott, D.; Partnering Initiative and UN DESA. The SDG Partnership Guidebook. A Practical Guide to Building High Impact Multi-Stakeholder Partnerships for the SusTainable Development Goals; The Partnering Initiative and UNDESA; United Nations and the Partnering Initiative: Oxford, UK, 2020.

49. Ordaz, E. The SDGs Indicators: A Challenging Task for the International Statistical Community. Glob. Policy 2019, 10, 141-143. [CrossRef]

50. Kvadsheim, N.P.; Nujen, B.B.; Mwesiumo, D. The Most Critical Decisions in Manufacturing: Implications for a Circular Economy; Springer International Publishing: Cham, Swizerland, 2021.

51. Khan, P.A.; Johl, S.K. Does adoption of ISO 56002-2019 and green innovation reporting enhance the firm sustainable development goal performance? An emerging paradigm. Bus. Strategy Environ. 2021, 30, 2922-2936. [CrossRef]

52. Rosati, F.; Faria, L.G.D. Business contribution to the Sustainable Development Agenda: Organizational factors related to early adoption of SDG reporting. Corp. Soc. Responsib. Environ. Manag. 2019, 26, 588-597. [CrossRef]

53. Zelinka, D.; Amadei, B. Systems Approach for Modeling Interactions Among the Sustainable Development Goals Part 1: Cross-Impact Network Analysis. Int. J. Syst. Dyn. Appl. (IJSDA) 2019, 8, 23-40. [CrossRef] 
54. UN. Transforming Our World: The 2030 Agenda for Sustainable Development. 2016. Available online: https:// sustainabledevelopment.un.org/post2015/transformingourworld (accessed on 12 May 2021).

55. Brunelli, S.; Ranalli, F. SDGs Achievement: Commitment, Channels of Action and the Role of Integrated Reporting in the Disclosure Mechanisms. In Accountability, Ethics and Sustainability of Organizations: New Theories, Strategies and Tools for Survival and Growth; Brunelli, S., Di Carlo, E., Eds.; Springer International Publishing: Cham, Swizerland, 2020; pp. 45-64.

56. United Nations Statistics Division (UNSD) and custodian-agencies-for-eachindicators. In E-Handbook on Sustainable Development Goals Indicators, Proceedings of the 48th Session of the United Nations Statistical Commission, New York, NY, USA, 7-10 March 2017; United Nations: New York, NY, USA, 2017.

57. Haskins, C.; Forsberg, K.; Krueger, M.; Walden, D.; Hamelin, D. Systems Engineering Handbook; INCOSE: San Diego, CA, USA, 2006.

58. Gomes, V.M.; Paiva, J.R.; Reis, M.R.; Wainer, G.A.; Calixto, W.P. Mechanism for Measuring System Complexity Applying Sensitivity Analysis. Complexity 2019, 2019, 1303241. [CrossRef]

59. Bar-Yam, Y. Complexity Rising: From Human Beings to Human Civilization, a Complexity Profile. 2020; EOLSS publishers: Oxford, UK, 2002.

60. Fairclough, N. Critical Discourse Analysis: The Critical Study of Language; Routledge: New York, NY, USA, 2013.

61. Ministries. Norway's Follow-Up of Agenda 2030 and the Sustainable Development Goals; Norwegian Government: Oslo, Norway, 2016. Available online: https://www.regjeringen.no/en/dokumenter/follow-up-sdg2/id2507259/ (accessed on 15 September 2021).

62. Seafood, A. Sustainability Report. 2020. Available online: https://www.auss.no/sustainability/sustainability-report/ (accessed on 20 July 2021).

63. Lerøy. Sustainability Report. 2019. Available online: https://www.leroyseafood.com/en/sustainability/sustainability-report-20 19/ (accessed on 21 July 2021).

64. MOWI. Mowi_Annual_Report_2019. 2019. Available online: https://corpsite.azureedge.net/corpsite/wp-content/uploads/20 20/03/Mowi_Annual_Report_2019.pdf (accessed on 21 July 2021).

65. Greig. Greig Seafood Annual Report. 2019. Available online: https://investor.griegseafood.com/reports-\&-presentations (accessed on 21 July 2021).

66. Nova-sea. Sustainability Report. 2019. Available online: https://novasea.no/miljo-og-samfunn/\#baerekraftsrapport (accessed on 22 July 2021).

67. SALMAR. Sustainability Report. 2019. Available online: https:/ /www.salmar.no/en/annual-reports/ (accessed on 28 July 2021).

68. Cargil. Sustainability Report. 2019. Available online: https://www.cargill.com/sustainability/aquaculture/aquaculturesustainability-reporting (accessed on 28 July 2021).

69. BioMar. Integrated Sustainability Report 2019. 2019. Available online: https://www.biomar.com/en/global/sustainability/ sustainability-report/ (accessed on 28 July 2021).

70. Cermaq. Sustainability: Goals and Focus Areas. 2020. Available online: https://www.cermaq.com/sustainability/goals-andfocus-areas (accessed on 28 July 2021).

71. Skretting. Sustainability Report. 2019. Available online: https://www.skretting.com/siteassets/global/sustainability/pdfs/ sustainability-report-2019.pdf?v=4aef7d (accessed on 5 August 2021).

72. Norwegian_University_of_Science_and_Technology_NTNU. UN Sustainable Development Goals and Partnerships. Available online: https://www.ntnu.edu/research/experts/un-sustainable-development-goals-partnerships (accessed on 16 September 2021).

73. UIB. SDG Bergen. 2020. Available online: https://www.uib.no/en/sdgbergen (accessed on 16 September 2021).

74. UIO. Oslo SDG Initiative. 2020. Available online: https://www.sum.uio.no/english/sdg/ (accessed on 14 September 2021).

75. NMBU. NMBU Sustainability Arenas 2021-2024. 2021. Available online: https://www.nmbu.no/en/research/funding/intern/ node/41355 (accessed on 21 September 2021).

76. Arctic_University_of_Norway. The Frames of SDG 16: Peace, Justice and Strong Institutions. 2021. Available online: https: / / uit.no/tavla/artikkel/741897/the_frames_of_sdg_16_peace_justice_and_strong_i (accessed on 17 September 2021).

77. University_of_Stavanger. 2020. Available online: https://www.uis.no/en/clean-plastic-discharges-rivers (accessed on 14 September 2021).

78. University_of_Agder. SDG. 2021. Available online: https://www.uia.no/en/content/search?q=SDG (accessed on 15 September 2021).

79. University_of_South-Eastern_Norway. Research. 2021. Available online: https://www.usn.no/english/research/our-research/ nature-health-and-environment/climate-change-and-alpine-ecosystems/ (accessed on 17 September 2021).

80. OsloMet-Oslo_Metropolitan_University. SIFO_Works towards the UN Sustainable Development Goals. 2021. Available online: https://www.oslomet.no/en/about/sifo/work-towards-un-sustainable-development-goals (accessed on 18 September 2021).

81. University, N. Research. 2021. Available online: https://www.nord.no/en/Search/Pages/results.aspx?k=SDG (accessed on 18 September 2021).

82. sjømatnorge. Aquaculture 2030 Think globally, Act Locally. 2017. Available online: https://sjomatnorge.no/wp-content/ uploads/2014/04/Havbruk-2030_final_EN_pdf.pdf (accessed on 14 September 2021).

83. GSI. Global Salmon Initiative (GSI): Commitment to Sustainable Development Goals. 2016. Available online: https: //globalsalmoninitiative.org/en/about-us/sustainable-business-practices/sustainable-development-goals / (accessed on 18 September 2021). 
84. Tiller, R.; Richards, R.; Salgado, H.; Strand, H.; Moe, E.; Ellis, J. Assessing Stakeholder Adaptive Capacity to Salmon Aquaculture in Norway. Consilience 2014, 11, 62-97.

85. Bailey, J.L.; Eggereide, S.S. Mapping actors and arguments in the Norwegian aquaculture debate. Mar. Policy 2020, 115, 103898. [CrossRef]

86. Cojocaru, A.L.; Iversen, A.; Tveterås, R. Differentiation in the Atlantic salmon industry: A synopsis. Aquac. Econ. Manag. 2021, 25, 177-201. [CrossRef]

87. Oslo-University. Course: Achieving the SDGs; Global Goals and National Interests. 2020. Available online: https:/ /www.sum. uio.no/english/sdg/studies/SUM4501/ (accessed on 24 September 2021).

88. Farooq, Q.; Hao, J.; Liu, X.; Xiao, D.; Hao, Y. Social and environmental development: Fresh concepts and soft measures towards sustainable development. Sustain. Dev. 2020, 28, 1796-1803. [CrossRef]

89. Abualtaher, M.; Bar, E.S. Review of applying material flow analysis-based studies for a sustainable Norwegian Salmon aquaculture industry. J. Appl. Aquac. 2019, 32, 1-15. [CrossRef]

90. Strategy. In Strategy for a Competitive Norwegian Aquaculture Industry; Ministry of Fisheries and Coastal Affairs: Bergen, Norway, 2007.

91. leroyseafood. Sustainability Report 2019. 2020. Available online: https://www.leroyseafood.com/no/barekraft/ barekraftrapport-2019/ (accessed on 24 October 2020).

92. Biomar. Sustainability report 2018. Available online: biomar.com (accessed on 15 September 2021).

93. MOWI. Salmon Farming Industry Handbook. 2020. Available online: https://mowi.com/it/wp-content/uploads/sites/16/202 0/06/Mowi-Salmon-Farming-Industry-Handbook-2020.pdf (accessed on 15 September 2021).

94. Stead, S.M. Using systems thinking and open innovation to strengthen aquaculture policy for the United Nations Sustainable Development Goals. J. Fish Biol. 2019, 94, 837-844. [CrossRef]

95. Fessehaie, J.; Morris, M. Global Value Chains and Sustainable Development Goals: What Role for Trade and Industrial Policies; International Centre for Trade and Sustainable Development (ICTSD): Geneva, Switzerland, 2018.

96. Schaltegger, S.; Bennett, M.; Burritt, R. Sustainability Accounting and Reporting. Sustainability Accounting and Reporting; Springer: Dordrecht, The Netherland, 2006; Volume 21, p. 704.

97. Brockett, A.; Rezaee, Z. Corporate Sustainability: Integrating Performance and Reporting (Volume 630); John Wiley \& Sons: Hoboken, NJ, USA, 2012.

98. Hristov, I.; Chirico, A. The Role of Sustainability Key Performance Indicators (KPIs) in Implementing Sustainable Strategies. Sustainability 2019, 11, 5742. [CrossRef]

99. Parmenter, D. Key Performance Indicators: Developing, Implementing, and Using Winning KPIs; John Wiley \& Sons: Hoboken, NJ, USA, 2015.

100. Fonseca, L.; Carvalho, F. The Reporting of SDGs by Quality, Environmental, and Occupational Health and Safety-Certified Organizations. Sustainability 2019, 11, 5797. [CrossRef] 